\title{
A comparison of two Turkish grinding stone assemblages: Kilise Tepe, Mut and Kinet Höyük, Dörtyol
}

\section{David Helsop}

\begin{abstract}
Kilese Tepe and Kinet Höyük are important multi-period sites in south-east Turkey that produced important assemblages of querns. These were analysed to provide insights into the source of the lithology, evidence for patterns of usage and fragmentation, and clues to the uptake of technological innovations.
\end{abstract}

Keywords: querns, stones, trade, innovation, Turkey, Kilese Tepe, Kinet Höyük

David Helsop, archaeologist, New Visions Heritage Ltd, david@new-visions.co.uk

\section{Introduction}

This paper, presented in advance of full publication, is a discussion of some of the most interesting aspects of the research on the grinding stones from Kilese Tepe and Kinet Höyük, two major sites from South-East coastal Turkey (Fig. 1).

Kilese Tepe (Fig. 2), 40 kilometres north of Silifke, is the largest investigation of a pre-Classical settlement site in western (Rough) Cilicia. It was excavated by the Universities of Cambridge and Newcastle between 1994 and 2011 under the direction of Nicholas Postgate and Mark Jackson. Thirteen metres of archaeological deposit make up the occupation mound, which starts in the Early Bronze Age and concludes with the abandonment of the medieval church (Postgate and Thomas 2007).

Kinet Höyük, 30 kilometres north of Iskenderun on the sea near Dörtyol (Fig. 3), is the largest
pre-Classical site in eastern Cilicia (modern Çukurova). Excavations began in 1992, under direction of M.-H. Gates and with the institutional backing of Bilkent University (Ankara). By the time fieldwork at Kinet Höyük concluded in 2012, excavations on the mound and in surrounding fields had recovered a continuous sequence from the Early Bronze II through the Hellenistic Period, capped by two centuries of medieval occupation.

The sites provide the opportunity to look at the quern evidence on densely occupied, relatively important settlements that were continuously occupied for three millennia. The sites are about 220 kilometres apart, both, at least in their general traits, would be described as belonging to the general Cilician Culture of this part of south-eastern Coastal Turkey in the 2nd and 1st millennium BC, both speaking the LUWIAN dialect. 


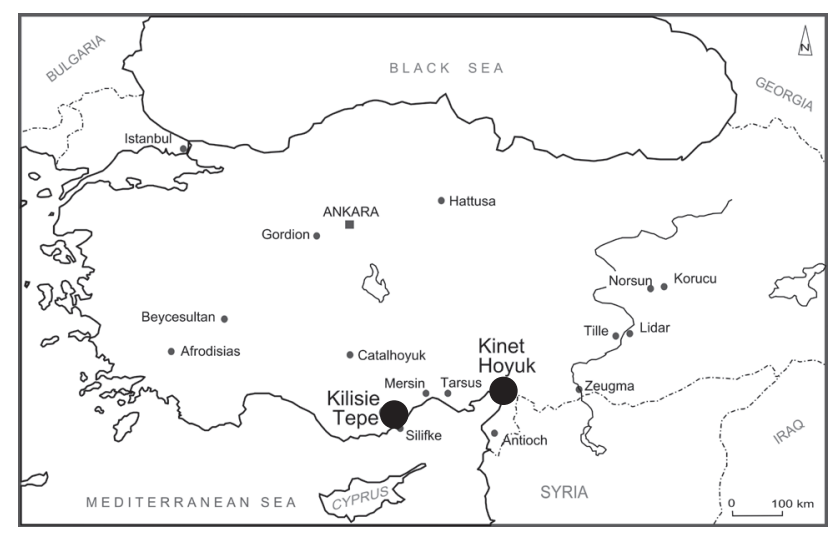

Fig. 1: Location of the settlements of Kilise Tepe (Mut) and Kinet Höyük (Dörtyol).

Of particular importance, is the fact that both sites are located on major communication and trade routes. Kinet Höyük was a major regional port with a developed maritime economy and Kilise Tepe was a stop-off on the road through the Göksu Valley, the shortest route from the Mediterranean through the Taurus Mountains to the Konya plain and central Anatolia. Through these routes travelled people, goods and ideas that linked the surrounding external cultures: the Mycenaeans, the Cypriots, the Assyrians, the Babylonians, the Phoenicians, the Greeks, and finally the Persians and the Romans.

The excavations have long sequences of occupation, normally continuous but with occasional violent interruptions. Both start in the Early Bronze Age, and have important Middle Bronze Age phases. The Later Bronze Age-Iron Age transition is particularly important at Kilise Tepe where a cult complex with a possible temple-like structure (the Stele building) spans this important period of great change, when the central authority of the Hittite Empire was replaced by regional authorities.

The Classical and Post-Classical periods are also well represented but with different political emphasis. There is significant Persian influence at Kinet Höyük, but then a gradual decrease of the settlement until its abandonment in the 1st century BC. There is significant Byzantine presence at Kilise Tepe with a number of houses clustering round a basilica.

\section{The analysis}

Post-Excavation work is at different stages on the two projects: At Kinet Höyük, the basic phasing has been resolved but the detailed analysis has not started here (Bouthillier et al. 2014). The full catalogue is complete, and there are measured drawings for the 157 querns from Kinet Höyük (Fig. 4).

By contrast, Bronze Age levels have been published regarding the site of Kilise Tepe, and the 170 querns of this assemblage have been analysed. The analysis has to resolve the usual dilemma of how far the sequence can be broken-down into discrete chronological phases; if there are too many phases, the number of examples in each becomes too small to be statistically reliable, and if there are fewer phases you have more querns in each, but have less

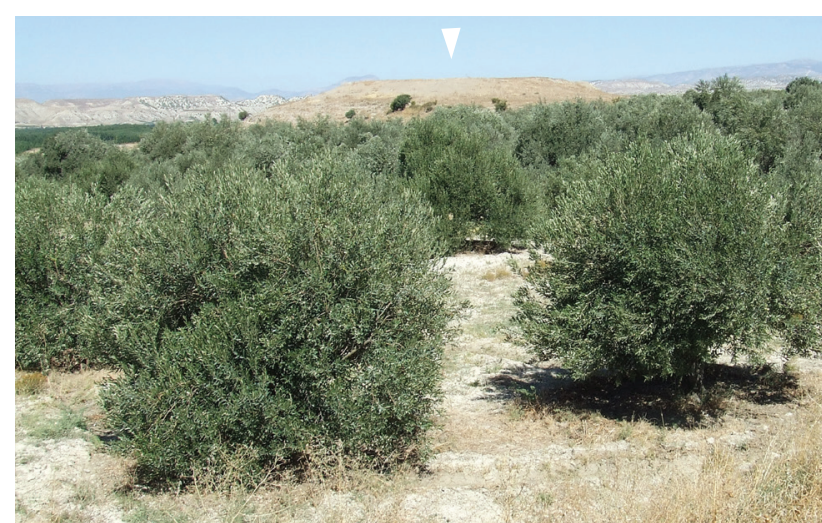

Fig. 2: Kilise Tepe: View of the mound from the East.

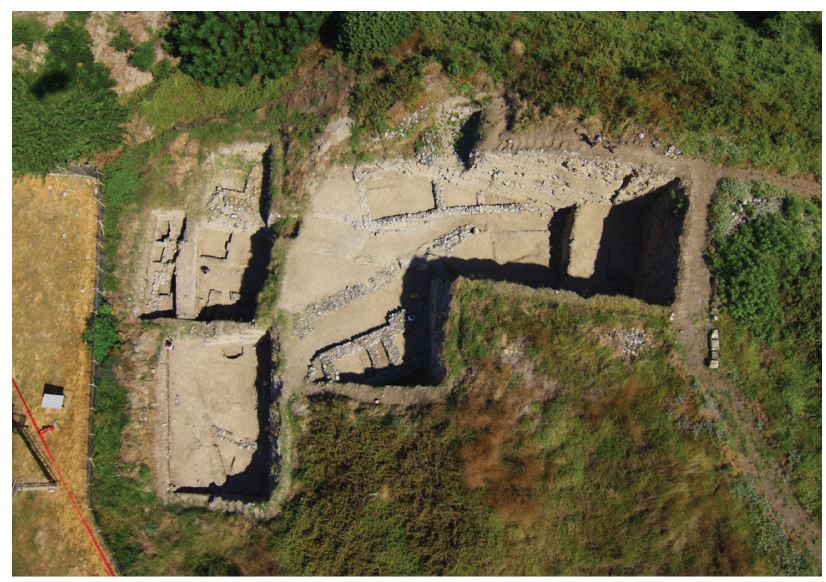

Fig. 3: Aerial view of the west end of Kinet Höyük with Early Bronze Age trenches on the left and Late Bronze Age on the right (photograph courtesy of Kinet Höyük Archive).

chance of detecting subtle chronological developments through the sequence. With the agreement of the excavation director, Nicholas Postgate, the quern assemblage has been split into four main phases: Early and Middle Bronze Age; Late Bronze Age; Iron Age; and Hellenistic/Byzantine.

The detailed analysis follows four main themes; lithology, form, usage and fragmentation. Lithology is concerned with acquisition whether by exchange across distance or the use of local resources. Form links to lithology, in that regional production centre may use different forms, but consistent forms may be evident across a range of lithological types, showing that specific mental templates were widely employed and maintained over considerable periods of time. Changes in form can be used as an indicator of the uptake of technological innovation by these communities. One specific innovation of great interest in quern studies is the dating of the use of rotary types to replace saddle querns in the Classical period. Use can be important for giving insights into the social organisation of communities under study, but also includes evidence of secondary usage and adaption for other functions. The degree or amount of wear shown by the stones at the point at which 


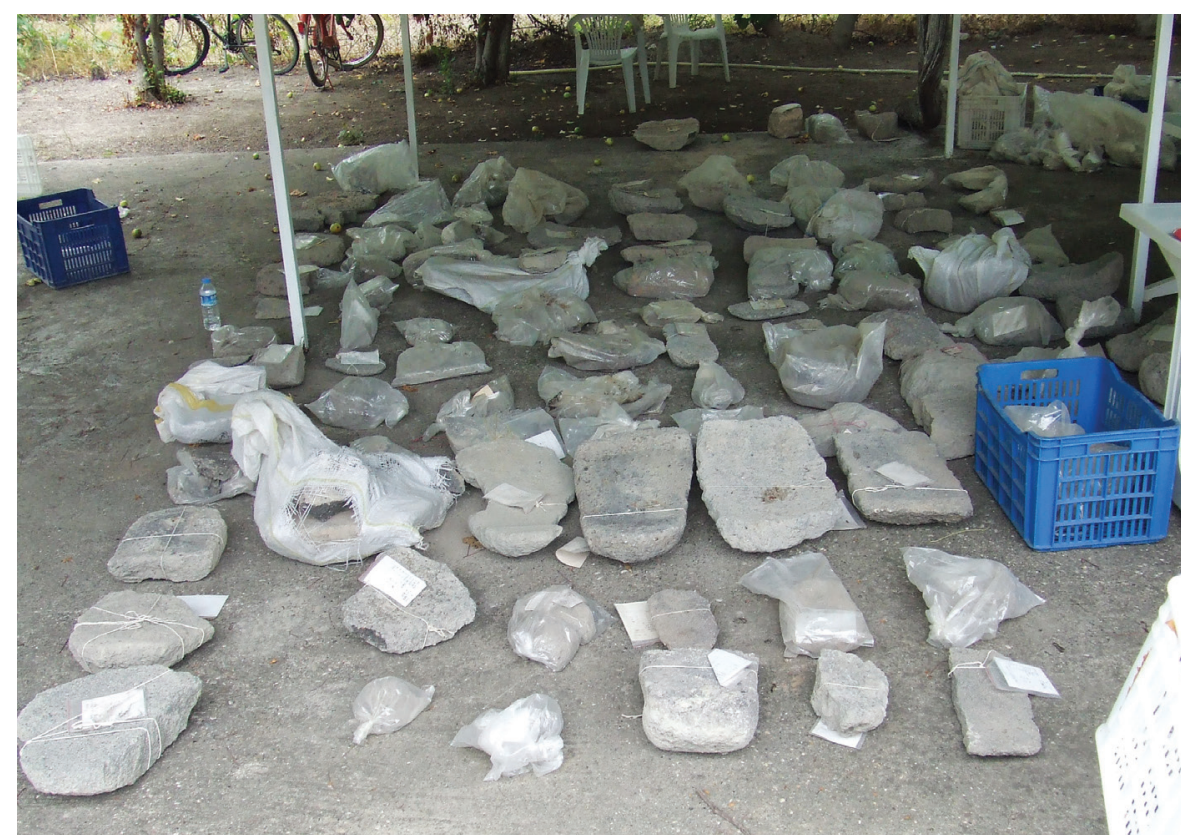

Fig. 4: The Kinet Höyük quern assemblage during recording.

they were discarded is also important in indicating at what point the stones were regarded as being no longer functionally useful for processing cereal. As this point, fragmentation comes into the picture. It is clearly linked to lithology, for example, lava is a very brittle and easily broken rock type but basalt is very tough, difficult to work, and much less prone to accidental fracture. But it also links to form, with very clear patterns of alteration to change the function of the object.

This account will concentrate on four topics of discussion which spring from these four main themes and will make comparisons between the two sites to attempt to provide insights into the way the objects were procured and used. The topics are: acquisition of suitable rock sources; evidence of how querns were used; fragmentation; and the uptake of technological innovation.

\section{Raw material acquisition}

This account has stressed the many similarities between the two sites. Yet there is a fundamental difference between the two assemblages regarding their access to suitable raw material.

Kinet Höyük is 17 kilometres from a major source of quernable rock - the Toprakkale lava field. A majority $(99 \%)$ of the querns at Kinet Höyük are hewn from a vesicular lava, a rock with excellent milling properties that is light-weight and easy to work. Acquisition of suitable raw material was not an issue for the communities at Kinet Höyük as there was a nearby plentiful supply of high-quality material to meet all of their cereal-processing requirements. It was sufficiently available to be used as a building material, for large plinths, and foundation slabs. Many hundreds of tons of lava were imported onto the settlement.

The only observable variation in the Kinet Höyük lava assemblage is the marked variation in the texture of the lava which have been categorised into three bands (fine, medium and coarse) by visual comparison to reference examples (Fig. 5).

The assemblage at Kinet Höyük is made up of 156 lava querns, and a single example (Fig. 6) in a different lithology, a grinder (top stone, hand-
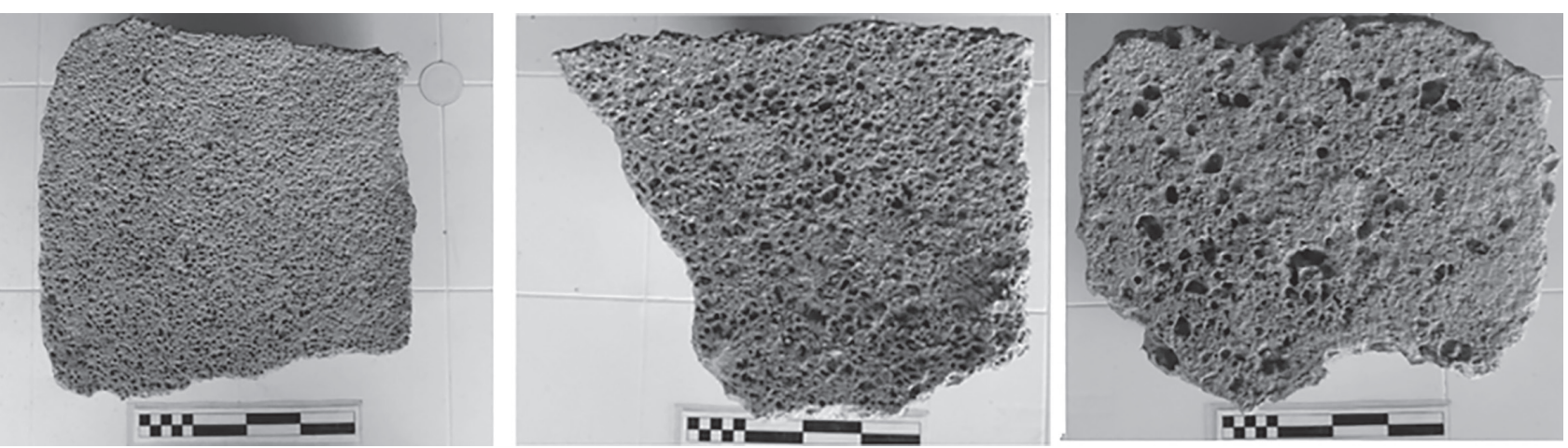

Fig. 5: Fine, medium and coarse vesiculated lava textures from Kinet Höyük. 

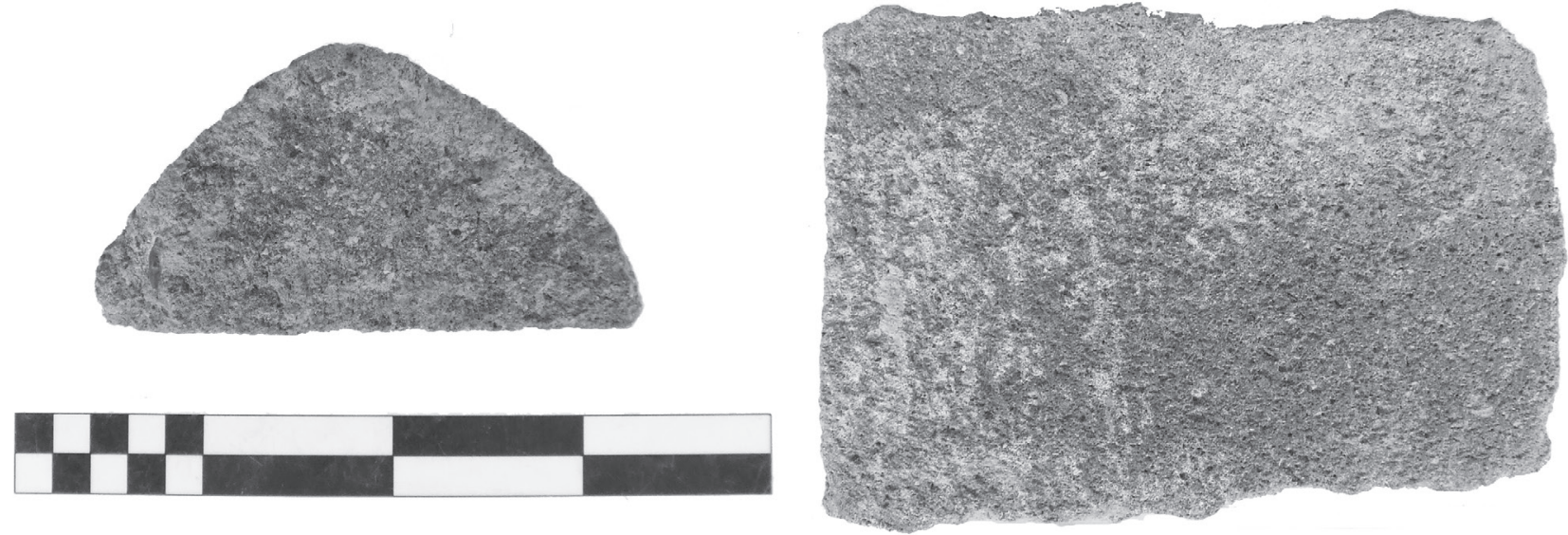

Fig. 6: Early Bronze Age igneous grinder from Kinet Höyük.

stone, rubber, rubbing stone, muller or mano are alternative terms for the upper element (Peacock 2013, 7) - grinder will be used here) which has a quern wear pattern on the grinding face. The lithology is a grey-green igneous rock, of uncertain, but distant provenance. Interestingly, this came from the earliest phase in the sequence, the Early Bronze Age.

By contrast, Kilise Tepe is situated in a broad sedimentary plain of Miocene marl and clay. The stone component consists of limestones and conglomerates washed downstream by the river. From the position of the surviving abutments of the Roman bridge across the Göksu, it is clear that the contemporary Roman surfaces have long ago eroded away and been washed down the Göksu Valley.
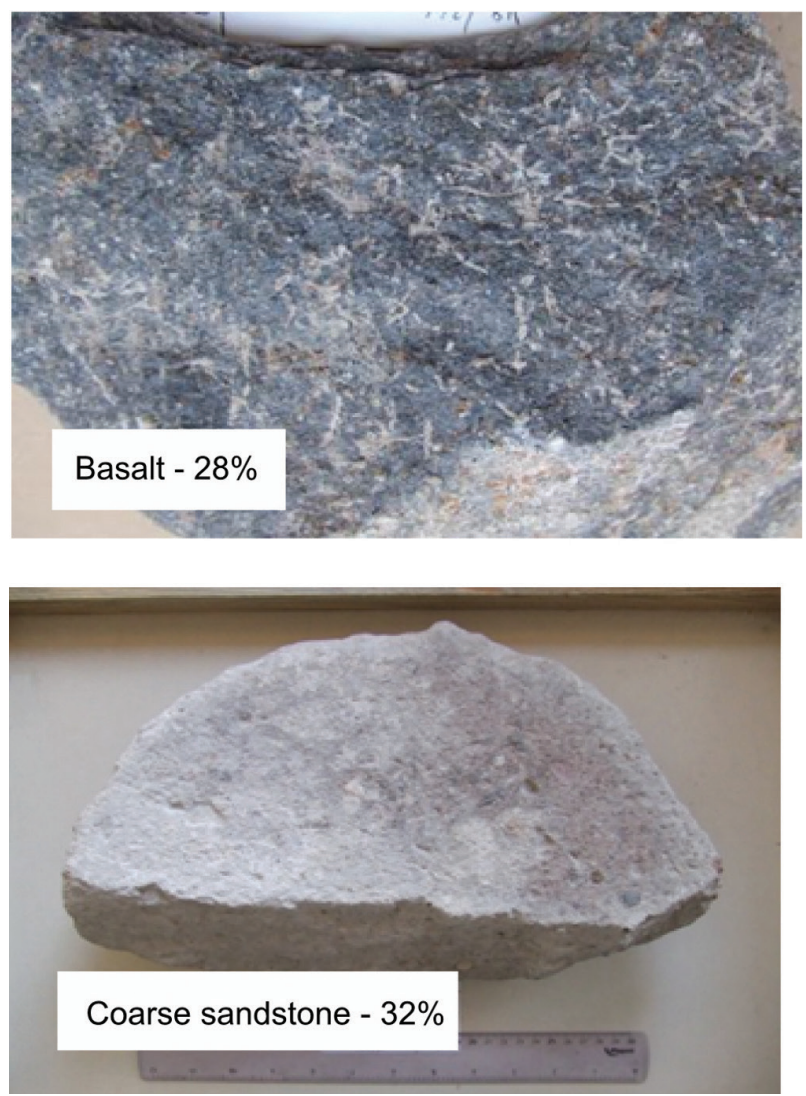

The communities at Kilise Tepe had to procure suitable cereal milling equipment to process the wheat and barley crops, which palaeo-environmental evidence has shown to be the dietary staple of the community.

The Kilise Tepe assemblage has querns from four lithological sources. Basalt makes up 28\% of the total assemblage; vesiculated lava makes up $20 \%$ of the total; medium-grained sandstone makes up 32\%; and finally, conglomerates and limestones make up 20\% (Fig. 7).

Where did the imported Kilise Tepe querns come from? The nearest source for the basalt is 100 kilometres away, to the north, or possibly along the coast to the west. Studies of quern lithology
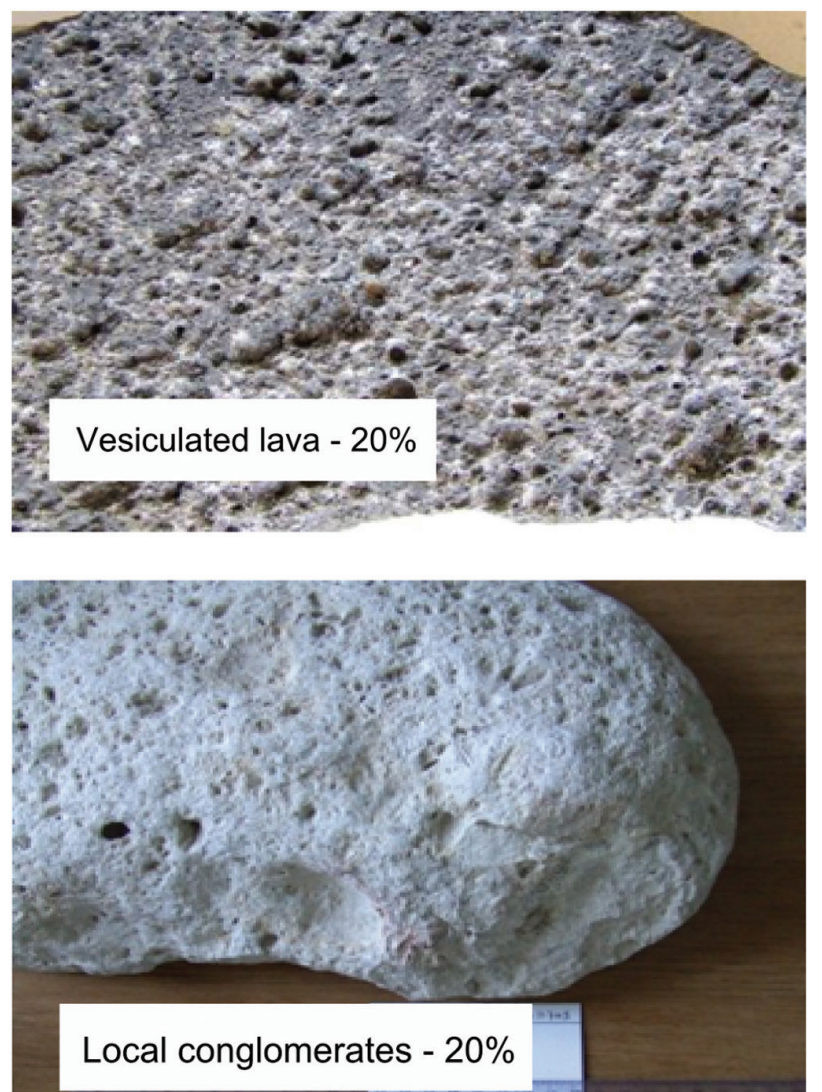

Fig. 7: Lithological types from Kilise Tepe. 
in Turkey are not as well-advanced as in Syria and Jordan, where Graham Rutter and Graham Philip, among others, have worked on the geochemical finger-printing of basalt ground-stone objects (Rutter and Philip 2008, 343). The technique can point to the general formations likely to be the sources of specific querns, although, to date no actual quarry site has been found through chemical analysis alone.

The small band of igneous exposure immediately to the north of the site is not a quern source, but a serpentine, which was important for making seals and intaglios in the Late Bronze and Iron Ages, but not for ground stone objects.

Among the stone finds from Phase 2e (1150-800 BC) was a block of basalt that had the beginnings of working to form a curved surface, but which had been discarded, presumably when it had fractured during the manufacturing process (Fig. 8). The obvious conclusion is that it was it imported as a blank or rough-out for final shaping on the site? Less than $10 \%$ of the surface area of the mound has been excavated. It is possible that manufacturing zones on the edge of the main settlement have not been found, where imported raw material was made into finished objects.

The lava querns are counted as $20 \%$ of the total, but are the most heavily fragmented type. Only two reasonably complete artefacts found, both round backed grinders - these could originally have been loaf-shaped and been used until they were completely worn-out. They both come from the Iron Age phase, and they could have come from the same Toprakkale lava field production site as the Kinet Höyük querns, but as the geotechnical fault line between the Anatolian Plate and the Asian Plate runs through Cilicia, making it one of the most volcanically active regions in the world, there are a number of similar lava fields in the vicinity.

The best of the sedimentary rock within the assemblage are medium to coarse sandstones, which probably come from sources in the mountains to the north - perhaps 30 to 40 kilometres away. Half a dozen are in a visually similar hard-grey dense sandstone, present throughout the assemblage phasing. These are more roughly-shaped than the basalts and lava querns.

A fifth of the assemblage is made up of very local stones (limestones and conglomerates), which are readily available as surface boulders in the River Göksu, but which have extremely poor milling properties. Where enough of the quern survives to appreciate the shape, they can be recognised as adapted water-rounded boulders with little or no finishing tooling to make the final form. Less than $10 \%$ are in the fined-grained white limestones, from which all of the mortars and grinding slabs on the site were made.

Figure 9 shows how the proportions of the different lithologies change through time.

Phase 1, the Early \& Middle Bronze Age, has a predominance of sandstone and basalt - few lava querns and only one local conglomerate. It is in Phases 2 and 3, the Late Bronze Age and Iron Age levels, that the local querns become important, and they tail off markedly in the later Hellenistic and Byzantine periods.

It is suggested that these poor-quality local stones are used to fill-in gaps in supply of the better-quality stones of all types, perhaps when the trading networks have been disrupted, or when the value of the finer-quality types is too high for the communities at Kilise Tepe. There is certainly a significant change in the ceramic assemblage, with a decline in the more exotic imports noted across the Bronze Age to Iron Age transition, and this is linked to developments in the wider history of the region. Alternatively, this may be an expression of social differentiation or stratification, with poorer or lower status families not having access to the better-quality querns.

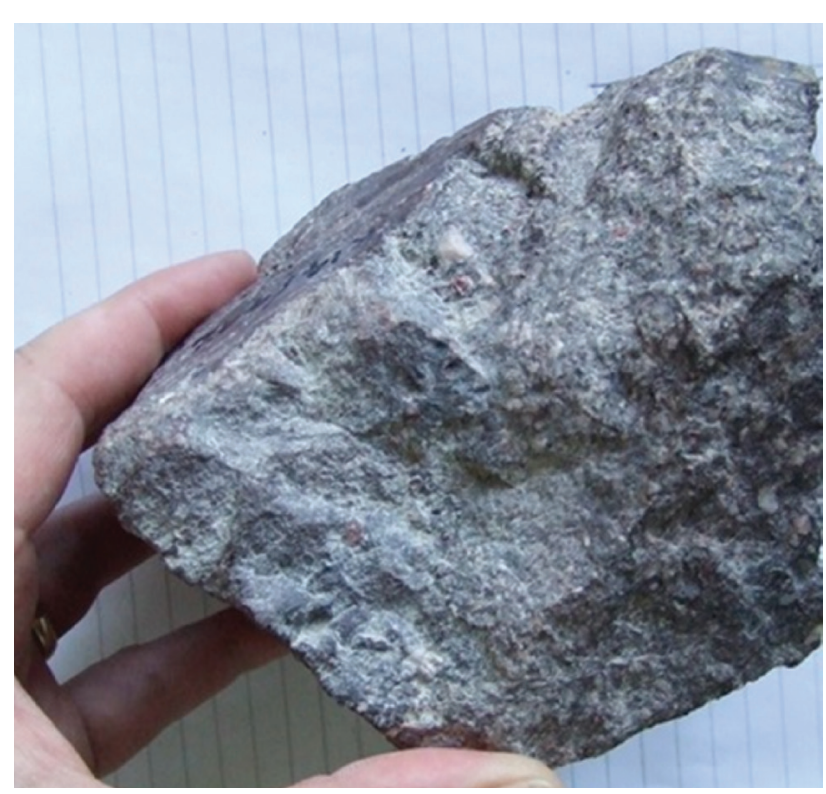

Fig. 8: Partly-worked block of basalt from Kilise Tepe.

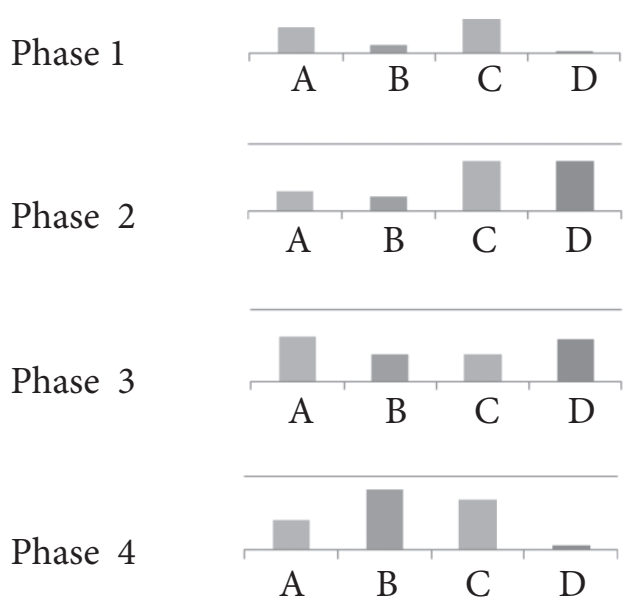

Fig. 9: Kilise Tepe: Lithology by quern phase. A) Basalt: present in varying quantities throughout the sequence. B) Lava: becomes more important through time. C) Sandstone: most important in the Early Bronze Age. D) Conglomerate and limestone: filling gaps when better materials were not available? 


\begin{tabular}{|l|r|r|r|r|r|r|}
\hline Fragmentation degree & 5 & 4 & 3 & 2 & 1 & \\
\hline Basalt & 0 & 1 & 4 & 3 & 0 & 8 \\
\hline Lava & 0 & 2 & 2 & 1 & 2 & 7 \\
\hline Sandstone & 5 & 2 & 10 & 2 & 4 & 23 \\
\hline Conglomerate and limestone & 2 & 0 & 4 & 2 & 2 & 10 \\
\hline Total & 7 & 5 & 20 & 8 & 8 & 48 \\
\hline
\end{tabular}

Fig. 10: Kilise Tepe: Degree of fragmentation by lithology for saddle querns. $5=$ complete; $>1=$ less than $20 \%$.

\section{Fragmentation}

The suggestion that there were gaps in supply is supported by the fragmentation evidence. Looking at fragmentation by lithology (Fig.10) the basalt querns, which are in the hardest, most durable lithology, are significantly more fragmented than the sandstone or conglomerate querns. There are no complete saddle querns in basalt, yet the type is important in all phases.

Furthermore, the basalt querns are significantly more worn, in many cases to exhaustion, and a couple have wear patterns on both main faces. There are significantly more grinders than saddle fragments in basalt ( 23 grinders, 7 saddles), but about the same number of grinders and saddles in the poorer lithologies, for example, the locallyprocured conglomerates and limestones (10 grinders and 10 saddles).
The logical inference is that when the basalt saddle querns become too thin in the centre to be used as base stones, the edges are converted into grinders. Fig. 11 shows two examples, both clearly grinders but showing evidence of an earlier life, and the second formed from an oval saddle with secondary tooling to make the grinder shape fit into the hand.

By contrast, there are significantly more complete and unworn limestone and conglomerate querns, like the lightly-worn example that was left in the section of an Iron Age level (Fig.12). It is a waterworn boulder of very poor quality. Was it only used when there weren't better quality types available, and then quickly discarded when a better quern was acquired?

\section{Usage}

Turning to evidence of how the querns were used. Kilise Tepe is the only example of a Byzantine rural settlement in Cilicia to be excavated on a significant scale. There have been many churches and monasteries dug but almost no work on the settlements of the actual population.

A typical building of the late 6th/ early 7 th century $\mathrm{AD}, 20 \mathrm{~m}$ from the basilica, had four rooms and a courtyard. The north-east room appears to have been used for food preparation, and although no querns were found in situ, a clay-lined pit in the courtyard nearby may have been for grain storage, and the clay and plaster floor contained a socket with a pottery vessel in situ. The room contained
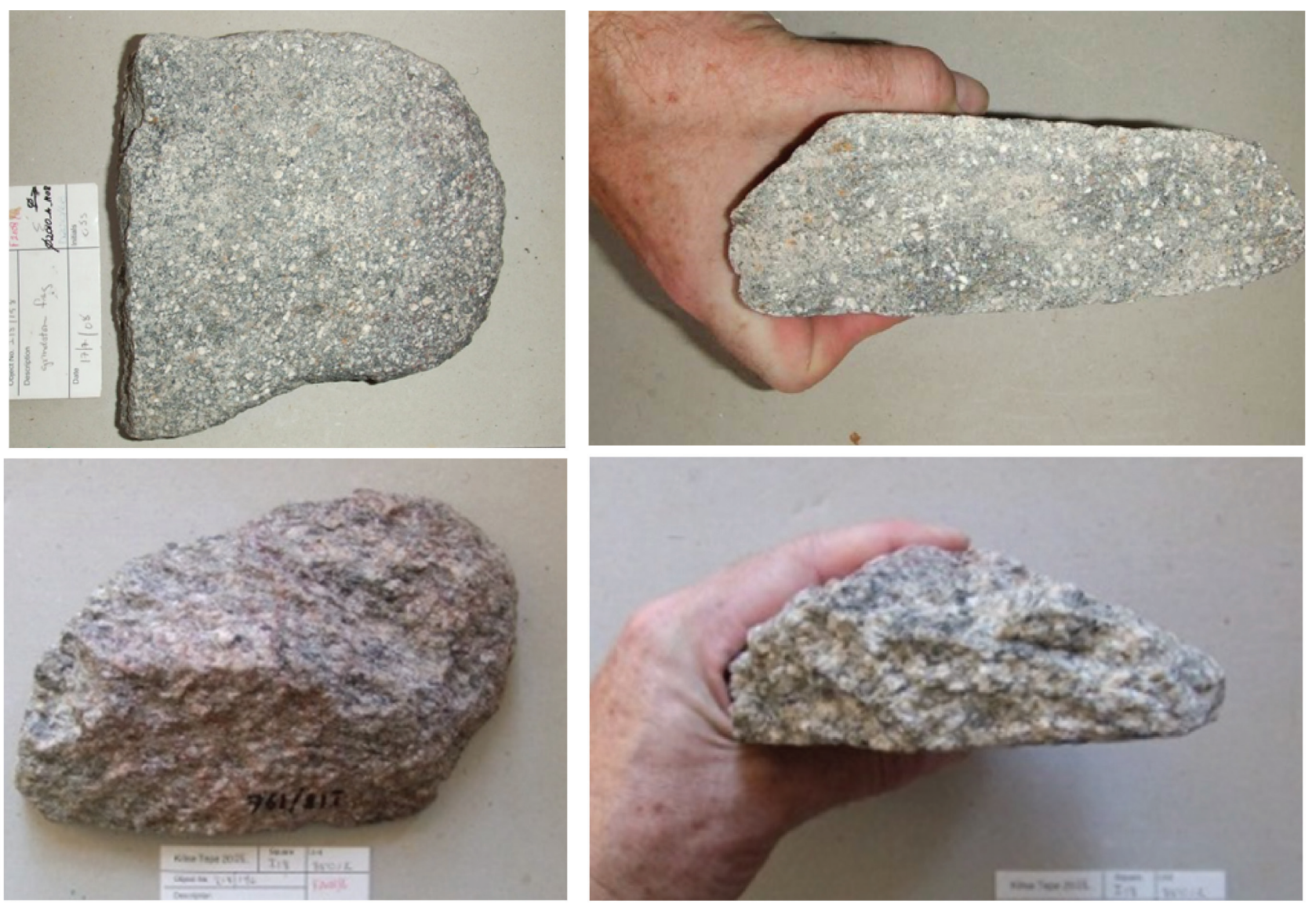

Fig. 11: Re-use of worn saddle quern as upper, grinding stone (different scales) at Kilise Tepe. 


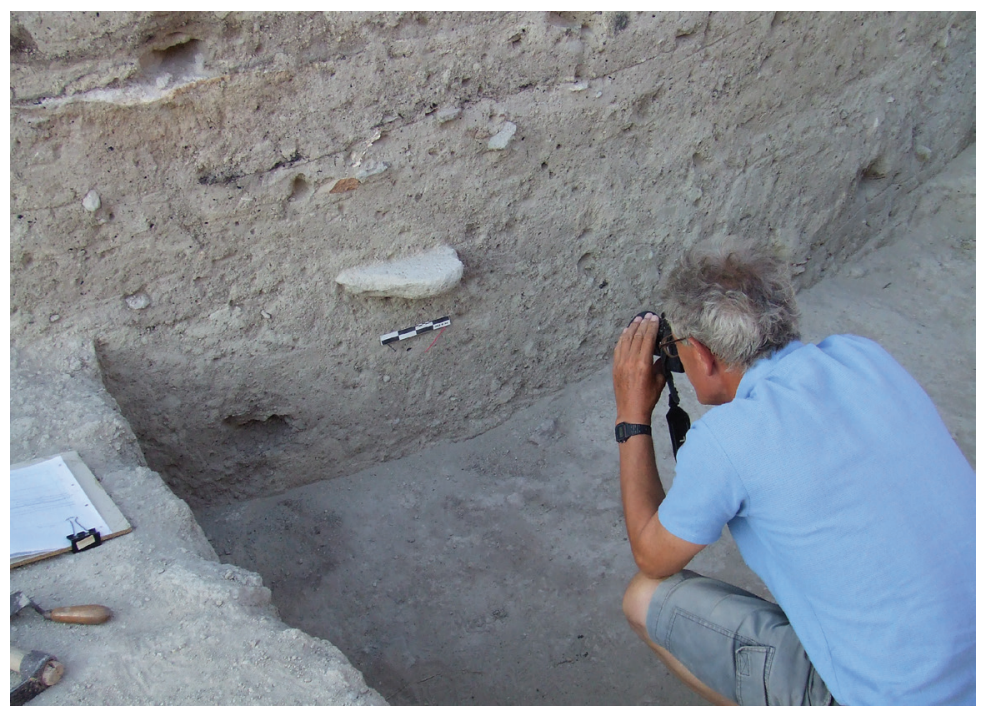

Fig. 12: A lightly-worn limestone saddle quern from an Iron Age level at Kilise Tepe.

a large bench of stone and a smaller one of dried brick. One of these may have been for flour milling.

At Kinet Höyük, the evidence was less equivocal. In the Middle Bronze Age, the town was subject to a devastating earthquake which resulted in the rapid accumulation of silt followed by a deposit of sterile soil with occasional shells, up to $1.2 \mathrm{~m}$ thick and all deposited at once according to radiocarbon dates from the deposit's top and base. The excavator believes this can only be interpreted as the result of a tidal wave, - a tsunami - sealing this Middle Bronze building with all its contents.

In one of the rooms (Fig. 13) there was an intact installation of three querns, inclined on a bench, with the grinders still in position, in spaces next to the saddles (Fig. 14). A ceramic vessel was found immediately by. It is interesting to see the way the saddles have been trimmed to fit the bench almost no overlap beyond the edge of the bench was tolerated on two of the base stones. Closer examination of the lava shows that the more complete example is a fairly coarse lava, the other two are finer, one slightly more so than the other. Did the meal pass from the coarse saddle before moving to the medium and then being finished-off on the finest? This gives us a clear indication of the kind of structural evidence we should be looking for at Kilise Tepe and other excavated sites in the region, and has implications for the social organisation of food-production within the community.

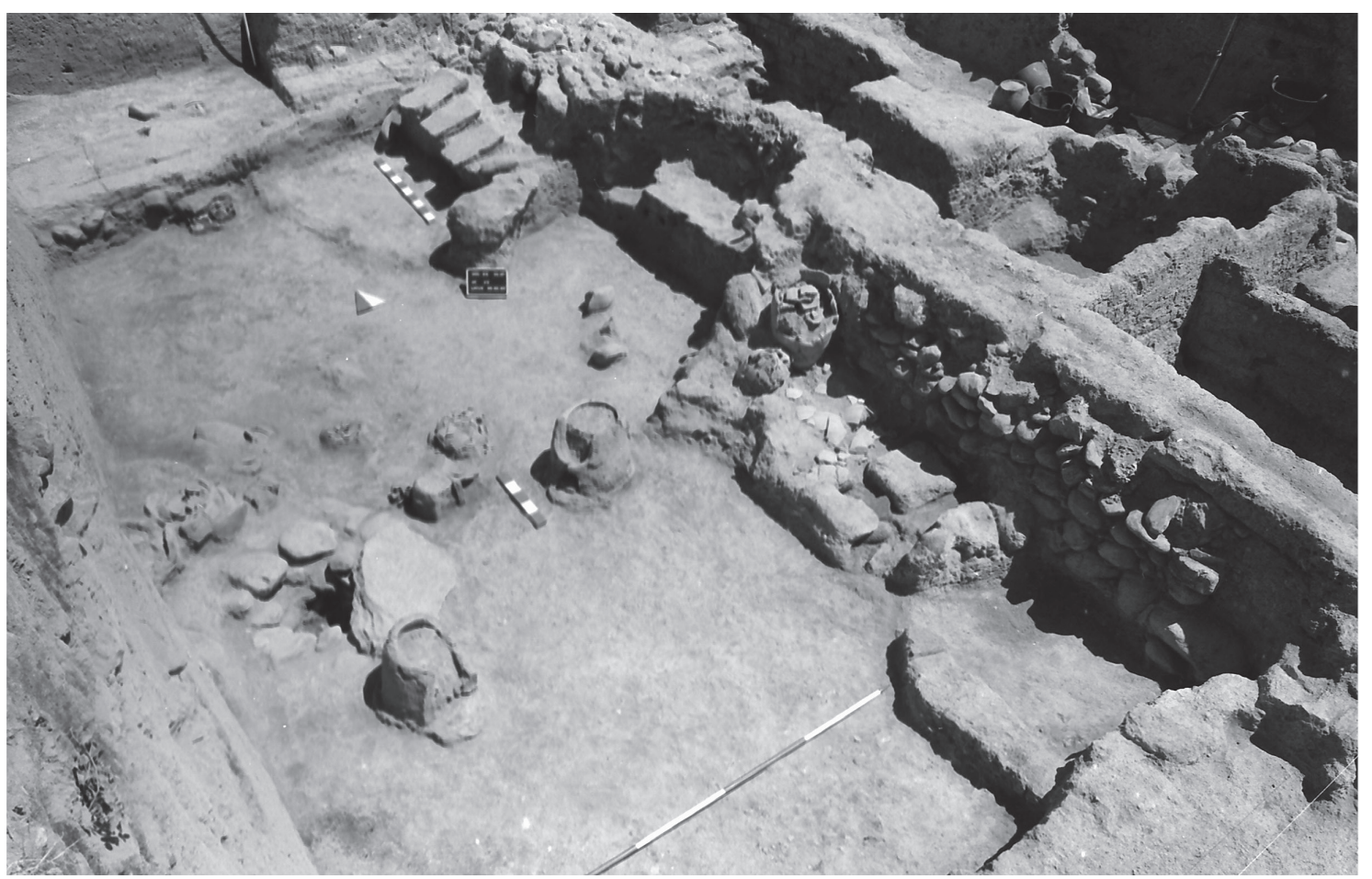

Fig. 13: Middle Bronze Age phase of tsunami destruction at Kinet Höyük; workshop room with quern installation at the top of the picture (photograph courtesy of Marie-Henriette Gates). 


\section{Technological innovation}

The fourth theme, the degree of uptake on new forms of quern, will highlight another interesting feature demonstrated by the two sites - the willingness or capability to embrace new technology. As stated above, both of these sites are on major trade routes but at both Kilise Tepe and Kinet Höyük there is no evidence that rotary querns, which were common from Ireland to China by the 2 nd century BC, were in use before the Medieval Period. By contrast, at Zeugma, on the Turkish Euphrates, a contemporary port settlement to Kinet Höyük with a long and complex history, there are rotary querns in the Roman horizons.

At Kilise Tepe, a single rotary quern lower stone (Fig. 15) was found among the collapsed columns and marble panels of the basilica, but without a clear date of use. It is in the same basalt as some of the prehistoric querns.

Because of the complex patterns of fragmentation and re-use mentioned above, it is not possible to know if the basalt saddle querns were still being exported from production sites in the Hellenistic and Byzantine periods, or were residual from earlier phases. It is possible that resistance to change is on the production side, rather than on the part of the communities acquiring the objects. Certainly, there are no rotary querns from any of the archaeological horizons at Kilisie Tepe, and the only stratified examples at Kinet Höyük date to the 12th to 14th centuries AD.

There is no obvious reason why new ways of doing things should be apparent in one part of Rough Cilicia, but completely lacking elsewhere. Given the lack of comparative evidence from other sites in Cilicia, it is unwise to be too sweeping in our generalisations, and the issues may be more complicated than purely the choice of the communities involved.

In other aspects of contemporary life, there is no suggestion that agriculturalists at Kilise Tepe were somehow intrinsically unwilling or unable to adapt to new technologies. One possible explanation is that the use and maintenance of rotary querns

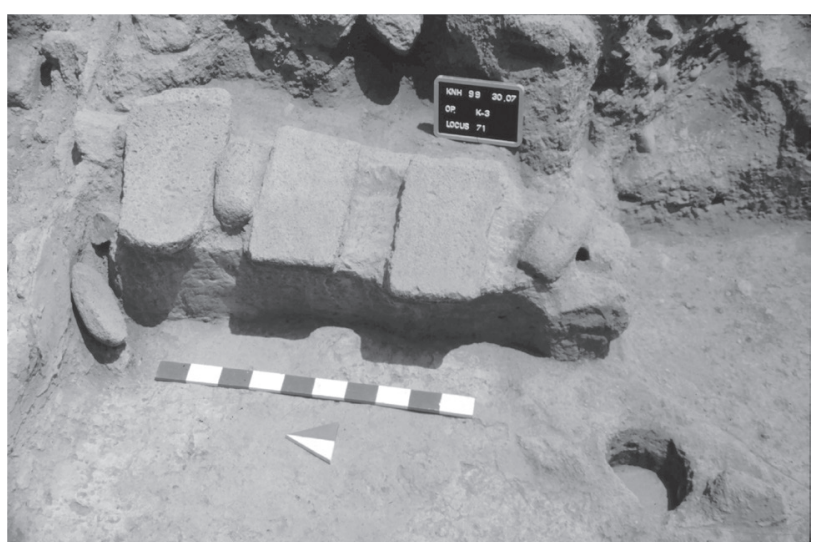

Fig. 14: Kinet Höyük: Middle Bronze Age phase of tsunami destruction; the quern working area (photograph courtesy of Marie-Henriette Gates). requires the use of iron components, as opposed to the saddle quern/grinder combination, that predates the introduction of metal technology. Rotary querns need metal spindles and handles, and they require drilling and chiselling to maintain the quern at optimum efficiency as it changes shape with use. At Kilise Tepe, there were only a couple of dozen fragments of iron nail from the whole excavation, and most of the pins and other smaller metal fixings were of copper alloy (Collon and Symington 2007, 515).

Furthermore, there is no evidence in the excavated area of any smelting or smithing activity, which may have been centrally controlled in other locations, perhaps close to fuel and ore sites. Similarly, the excavator at Kinet Höyük notes that it is only in the medieval period that iron becomes common (Marie-Henriette Gates, pers. comm.). If the communities at Kilisie Tepe and Kinet Höyük found accessing iron objects difficult, that may have been the determining factor that swung the cost/benefit balance away from investing in new quern types, and made it more sensible to continue with the use of saddle querns. This may explain why the move over to rotary querns was not made until later in the First Millennium AD, when iron was more widely available.

The study of these two sites has advanced a number of interesting questions which have relevance to wider research questions in the archaeology of southern Anatolia.
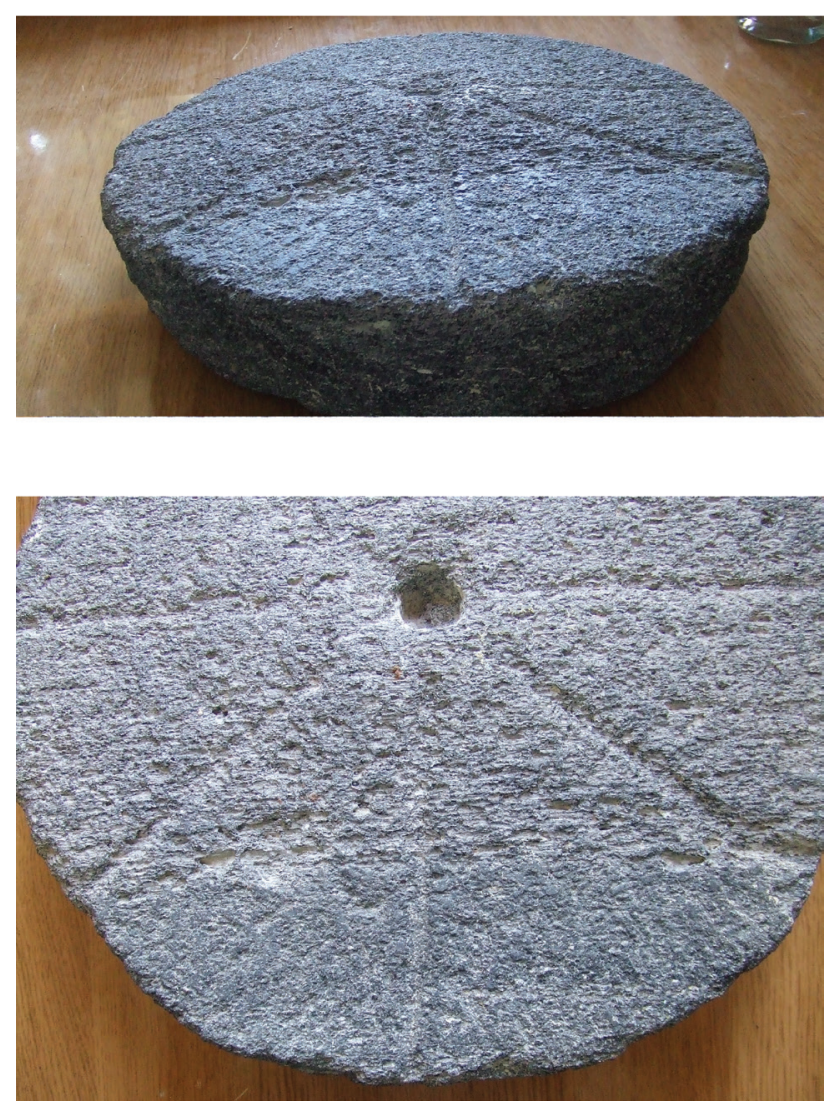

Fig. 15: Kilise Tepe: The single example of a basalt rotary quern lower stone. Diameter $=33.4 \mathrm{~cm}$, max. thickness $9.4 \mathrm{~cm}$. 


\section{Acknowledgements}

The author is extremely grateful to the directors of the research projects discussed (Nicholas Postgate and Mark Jackson for Kilise Tepe and Marie-Henriette Gates for Kinet Höyük) for making material available in advance of publication, and for generously giving their time to make helpful corrections and improvements to the text. I would also like to acknowledge the help and support of the Yorkshire Quern Survey, and I am particularly grateful for the contribution of John Cruse, the Project Co-ordinator.

\section{Bibliography}

Bouthillier, C., Colatoni, C., Debruyne, S., Glatz, C. Hald, M. M., Helsop, D., Kozal, E., Miller, B., Popkin, P., Postgate, N., Steele, C. and Stone A. (2014). Futher work at Kilise Tepe, 2007-2011: refining the Bronze Age to Iron Age transition. Anatolian Studies, 64: 95-161.

Collon, D. and Symington D. (2007). Metalwork. In: N. Postgate and D. Thomas (eds). Excavations at Kilise Tepe 1994-98. From Bronze Age to Byzantine in western Cilicia. Vols. I and II, British Institute at Ankara Monograph, 30. Oxford: 515-30.
JACKSON, M. (2013). Byzantine Settlement at Kilise Tepe in the Göksu Valley. In: M. C. Hoff and R. F. Townsend (eds). Rough Cilicia: New Historical and Archaeological Approaches. Oxford: 219-32.

Parton, H. (2013). Milling and Weaving Equipment, including Hand-held Stone Tools, Mortars, Querns, and Stone Vessels, Loom Weights, and Spindle Whorls. In: W. AylWARD (ed.). Excavations at Zeugma Conducted by Oxford Archaeology The Packard Humanities institute Monograph. Los Altos, California: 295-344.

Peacock, D. (2013). The Stone of Life: Querns, Mills and Flour Production in Europe up to AD 500. Southampton Monographs in Archaeology New Series, 1. Southampton.

Postgate, N. and Thomas, D. (eds) (2007). Excavations at Kilise Tepe 1994-98. From Bronze Age to Byzantine in western Cilicia. Vols. I and II. British Institute at Ankara Monograph, 30. Oxford.

Rutter, G. And Philip, G. (2008). Beyond Provenance Analysis: The Movement of Basaltic Artefacts through a Social Landscape. In: M. R. YorKe AND J. R. Ebeling (eds). New Approaches to Old Stones Recent Studies of Ground Stone Artifacts Equinox. London: 343-58. 
